The value of the academic award in initial teacher education: Key stakeholder perceptions of the masters level Postgraduate Certificate in Education in two English universities

Lorraine Thomas

School of Education, Newman University, Genners Lane, Bartley Green, Birmingham, B32 3NT, United Kingdom

Email: 1.thomas@newman.ac.uk

Tel: 01214761181 


\section{Acknowledgements}

The author would like to thank the teacher-educators and student-teachers who participated in this research. 


\title{
The value of the academic award in initial teacher education: Key stakeholder perceptions of the masters level Postgraduate Certificate in Education in two English universities
}

\begin{abstract}
The Postgraduate Certificate in Education (PGCE) has been a successful and popular initial teacher education (ITE) programme since the 1950s, with the masters level PGCE being successfully embedded within universities in England since 2007 and having high levels of student satisfaction. Recent White Papers, policy and reviews have undermined the academic award in ITE, however, favouring school-led initial teacher training and the minimum, essential professional award.

Located within the Secondary ITE phase in two English universities, this article presents the value of studying education and the academic award at pre-service level via key stakeholder perceptions from interviews with teacher-educators and student-teachers within a case study. Findings highlight improvements to student-teachers' knowledge and practice; enjoyment in working at a higher academic level; improvements to the ITE programme overall, including student-teacher support and student-teachers' articulation of knowledge and practice; and enhanced opportunities for employability, career advancement and gaining a masters degree.
\end{abstract}

Keywords: initial teacher education (ITE); initial teacher training (ITT); masters level (M level) study; Postgraduate Certificate in Education (PGCE); student-teachers; teacher-educators 


\section{Introduction}

The Postgraduate Certificate in Education (PGCE) is a one-year initial teacher education (ITE) higher education (HE) programme for graduates, which has been a very successful and popular ITE programme in England since the 1950s. Initially a level 6 award, the masters level (M level) PGCE (typically awarding sixty masters level credits) was widely and successfully embedded within universities in England from 2007 and has high levels of student satisfaction (Thomas 2013). Recent White Papers (DfE 2010, 2016), policy and reviews (e.g. Carter, 2015) have undermined the academic award in ITE, however, favouring school-led initial teacher training (ITT) and the minimum, essential professional award of qualified teacher status (QTS). This issue is a key area of debate in teacher education, particularly in England, and this article draws upon other research outlining the importance of university study for student-teachers and makes a further distinctive contribution to the debate.

Located within the Secondary ITE phase in two English universities, this article presents the benefits of studying the discipline of education and the value of the academic award at preservice level via key stakeholder perceptions from interviews with teacher-educators and student-teachers within a case study. The research focuses on key stakeholder perceptions of the M level PGCE, which is still currently the most popular means of entering the teaching profession in England, but is under threat from QTS only routes in which there is no study of education and no academic award in education. In particular, this qualitative research moves the debate forward by offering rich accounts of key stakeholder perspectives via studentteachers themselves (as the main key stakeholders, whose voice it is essential to ascertain) and teacher-educators within an in-depth case study of two universities. The findings also move the debate forward by highlighting the specific value of studying education and the value of the academic award in ITE for student-teachers in supporting them with their future teaching and to thrive within their chosen career.

\section{Context}

Through the Organisation for Economic Co-operation and Development's (OECD) Programme for International Student Assessment (PISA), school systems across the world are compared and contrasted, with Finland consistently scoring well in the last decade. Research 
concludes that one important reason why Finnish schools are so successful may be that Finnish teachers are generally highly educated, because every teacher must have a masters degree (Tryggvason 2009). In addition, the former 'New Labour' government commissioned a review of the most highly performing school systems in the world, which found that masters level study for teachers was instrumental in improving the quality of instruction in Finland's schools and was a contributing factor in the success of its school system (McKinsey 2007). Influenced by the McKinsey (2007) report the former New Labour government published The Children's Plan (DCSF 2007), which declared that to keep pace with international competitors it was necessary to further improve standards in schools and the status of teachers by moving to a masters qualified profession in England.

At the outset it is necessary to reflect briefly on the current political ideology of school-led initial teacher training and university-led initial teacher education in England, against which the voices of the teacher-educators and student-teachers in this research must be heard. The government's shift in emphasis away from initial teacher education towards initial teacher training, student-teacher/student to trainee-teacher/trainee; and teacher-educator to teachertrainer signifies more than merely changes in nomenclature. For example, in the increasing and political ideological drive for school-led ITT, the former United Kingdom (UK) Conservative-Liberal Democrat coalition and the current Conservative governments have undermined HE-led ITE by significantly reducing the numbers of places allocated to higher education institutions (HEIs) and increasingly allocated more places to school-led ITT providers in England. The White Paper, The Importance of Teaching (DfE 2010), undermined the academic award in university-led ITE in England by expanding school-led ITT and also increasing the proportion of time being spent in the classroom on school-based placements. The proportion of places allocated to school-led ITT providers was increased to 49\% by 2015 (UUK 2014). The Carter review of initial teacher training (Carter 2015, 14) further undermined HE-led ITE in England and the academic award of the PGCE, by recommending that applicants 'understand that QTS is the essential component of ITT and that a PGCE is an optional academic qualification', thereby promoting the professional award via school-led ITT and discouraging the academic award via university-led ITE. The White Paper Educational Excellence Everywhere (DfE 2016) reinforced this position, by also stating that by 2020 school-led providers will be in control of ITT; proposing to deregulate the teaching profession further by replacing QTS with a new professional award ratified by headteachers; and committing all schools to becoming academies - state-funded schools, 
which receive their funding directly from central government, rather than through a local authority. Parochialism may develop, however, by QTS only being ratified at a local level by headteachers and by schools moving out of local authorities, which highlights an even greater need to retain an independent academic award in ITE and maintain aspirations for a masters level profession to improve the status and expertise of teachers. Some neo-conservatives clearly consider teaching to be merely a practical skill (DfE 2010; Carter 2015; DfE 2016) which can be fully learnt in the classroom, but whilst it is very important for student-teachers to spend significant time in the classroom to gain experience, a further advance to school-led ITT and reduction of university-led ITE may well also lead to parochialism and mediocrity within the teaching profession. University-led ITE, however, provides student-teachers with the opportunity to undertake academic studies in education, to gain an underpinning knowledge of education and to synthesise theory with practice. Links between theory and practice are often difficult to make (Rivero García and Porlán Ariza 2004), but pupils' learning can be greatly advanced, however, if this issue is addressed effectively (Korthagen and Kessels 1996). Overall, it could be argued that the rejection of pedagogy and the preference for the type of teacher who will fit into the current school system will only reproduce, rather than transform, the school system, and in turn the social system (Simon 1981).

\section{The academic award in ITE}

Given the ideological and policy-validated stance that has existed for many years in England concerning greater school-led ITT, HEIs now find themselves in an increasingly competitive environment, in which a strong case needs to be made regarding the value of academic studies in education and the academic award in ITE. In addition to gaining the PGCE academic award, those who have successfully completed the course are recommended for QTS - the minimum and essential requirement to teach in state maintained schools in local authorities - after meeting the professional standards (see DfE 2012). This issue is significant, since HEIs have a dual academic and professional role which has worked very successfully for many years leading to world-class provision (TDA 2008a, 2008b) and recognition by the Office for Standards in Education (Ofsted) (2010a) - within its former inspection framework (Ofsted 2010b) - that the most outstanding ITT was found in HE-led provision. (Ofsted inspects and regulates ITT provision in England.) 
Although school-led ITT has been increased in England, other areas of the UK have resisted school-led ITT. In Northern Ireland and Scotland the only routes into teaching are via university-led ITE, either through a concurrent undergraduate route with QTS or a consecutive first degree and PGCE/ Postgraduate Diploma in Education (PGDE) in Scotland. Furthermore, Teaching Scotland's Future (Donaldson 2011), a review into teacher education in Scotland, confirmed the importance of maintaining teacher education in universities. Universities in Wales also remain central to the provision of ITE. Although there is schoolled ITT in Wales, there seems little appetite to move away from university-led provision, with school-led routes remaining very small compared with university-led courses (Furlong 2015).

Furthermore, the British Educational Research Association (BERA) and the Royal Society for the encouragement of Arts, Manufactures and Commerce (RSA) produced a review of the international research evidence on high quality teacher education (BERA-RSA 2014). The inquiry commissioned 7 teams of researchers to review international evidence on a range of different dimensions of teacher education; led a UK-wide call for evidence; and held a range of consultative meetings across the UK. As a result of their inquiry, BERA-RSA (2014) argue that there is robust evidence to suggest that the best ITE programmes internationally offer academic awards that are competitive, practice-focused and built on relevant educational research; and develop strong links between theory and practice, in a way that helps studentteachers to understand and explore the interconnectedness of educational theories and classroom practices.

In addition, and following the Carter review of initial teacher training (Carter 2015), the Universities' Council for the Education of Teachers (UCET) - which represents university education departments in the UK - took up the challenge of articulating for potential teachers, schools and policymakers the consensus view of universities in England regarding the value of the M level PGCE. The outcome of the consultation and national working group was the publication of The benefits to individual teachers, to schools and to the teaching profession of Masters level Initial Teacher Education (UCET 2016), which was subsequently disseminated to policymakers. In this document, UCET $(2016,1)$ argues that:

an academic award at $\mathrm{M}$ level offers the best mode of post-graduate teacher preparation, with significant benefits for the school system as a whole as well as to the individual as, captured in our own 'three Es': 
Equity - for all new teachers as they undertake their initial training in a diverse system and at the point when consistent judgements are being made on their 'licence to practice';

Entitlement - of children and young people to be taught by excellent teachers who are equipped to teach well and be autonomous professionals in the schools of the future and not just to cope in the present system;

Expectation - that all schools should be able to recruit well-qualified teachers and thereby contribute to the success and well-being of wider society through the excellent teaching and support for personal development, that enable children and young people to achieve in the broadest sense.

Furthermore, UCET (2016) set out the following themes as the added value of an academic award in ITE: promoting teaching as an aspirational and inspirational career; reinforcing the concept that becoming a teacher is to become an educator; and providing teachers with an academic award, which is recognised across the UK and internationally, all of which should also enhance the status of the teaching profession, which, it can be argued, is much needed in a profession which is bedevilled by insecurity and inferiority (Revell 2005). UCET (2016) also set out the following themes in relation to the value of the academic award in ITE: highlighting the need for teachers to be able to use research and evidence; giving teachers research skills, which are capable of bringing about change; and developing the essential skills of planning for progression, all of which should support school improvement. In addition, UCET (2016) highlighted that ITE linked to an academic award offers a coherent programme of professional learning, which is enhanced by adult professional learning in group study and contact with university tutors; and via the necessary input of strong subject specialists. UCET (2016) also argued that ensuring the teaching profession is qualified at masters level, in line with the practice in other parts of the UK and in international systems acknowledged to be excellent, is important for the status of the profession, school improvement and professional learning. Finally, UCET (2016) argued that the academic award in ITE ensures judgements on entry into the teaching profession are consistent and high quality, which is important for the status of the profession and school improvement. The outcomes above specifically relate to the M level PGCE, but most are obviously also relevant to undergraduate ITE programmes which are still a popular means of entry to teaching in primary schools in England. 


\section{Methodology and participants}

Working within an interpretivist paradigm, this research follows a qualitative research design (Merriam 2009). Commensurate with the interpretivist approach, a case study is used, in order to explore key stakeholders' perceptions and experiences as they naturally occur. This case study provides an account of perceptions of the M level PGCE in two HEIs in England and the narrative should provide an opportunity to lead to more critically-informed opinions regarding the value of the academic award for student-teachers. The case study itself may not be generalisable, since it focuses on 'a particular phenomenon with a view to providing an indepth account ... in that particular instance' (Denscombe 2003, 32), but case study research is not barred from producing general conclusions (Gomm et al 2000).

The two HEIs were chosen as a representative sample of universities with very successful Secondary PGCE programmes - i.e. large, well-established programmes, with consistently high Ofsted grades. The scheduling of data collection was an important factor and data were collected at the end of the academic year, which meant that student-teachers had a significant amount of experience regarding the M level PGCE. Purposive sampling (Given 2008) was undertaken to select teacher-educators and student-teachers, who would illustrate what is typical, normal or average according to their experiences and perceptions (Palinkas, Horowitz and Hoagwood 2015). Teacher-educators and student-teachers provide key stakeholder perceptions and contribute new knowledge regarding the value of the academic award in ITE. The rich accounts from these key stakeholders move the debate forward, as research to date in this key debate of teacher education has not focused on the key stakeholder perspectives, and it often appears that some voices are side-lined as governments make use of legislative power to privilege a particular paradigm of educational outcome (Tucker 1999). Data were collected via individual semi-structured interviews with teacher-educators and focus groups with student-teachers.

Semi-structured, individual interviews were conducted to gain 'valuable insights based on the depth of information gathered and the wisdom of 'key informants'" (Denscombe 2003, 189) i.e. the perceptions of teacher-educators (senior lecturers and principal lecturers) responsible for the delivery and/ or management of the M level PGCE, and also of two senior managers, with a wider leadership role overseeing ITE. Ten teacher-educators were interviewed (five from each HEI) across the range of Secondary subject areas, since respondents may have had 
differing perspectives based on their subject specialisms and in an attempt to gain a representative cross-section of members of staff. Of the two senior managers interviewed, one was from a Primary ITE background and one was from a Secondary ITE background.

Focus groups were used to interview student-teachers to gain their collective perceptions of the M level PGCE. Focus groups 'get high-quality data in a social context where people can consider their own views in the context of views of others' (Patton 2002, 386) and are also a useful way of discovering 'insights that might not otherwise come to light' (Denscombe 2003, 169). Student-teachers were chosen from across the subject areas for the reasons indicated above. Fifteen student-teachers were interviewed (six from HEI 1 and nine from HEI 2, since the HEIs have six and nine subject areas respectively within their Secondary ITE portfolio).

Research is limited in that respondents were mainly from the Secondary ITE phase and Primary ITE phase respondents may have different perceptions. Also student-teachers, who are at the pre-service level, have not yet embarked upon a career in teaching and so are not yet fully aware of the value of their knowledge in education and the contribution of the academic award in education to practice.

The research was subject to approval by the University's ethics committee detailing matters of informed consent, the right to withdraw, academic integrity and the security of data. Anonymity of responses was assured. Permission to undertake the research was gained from each participant. Information was given to respondents regarding the research being undertaken and they were given every opportunity to disclose their thoughts within a safe environment. Interviews were recorded and took approximately one hour. Interviews were then transcribed. The analysis of qualitative data consisted of data reduction, data display and conclusion drawing/ verification (Miles and Huberman 1994).

\section{Findings and discussion}

A range of themes regarding the perceived value of the M level PGCE were identified from interviews with teacher-educators and student-teachers. These themes are illustrated below through the use of direct quotations. Common themes identified by both teacher-educators and student-teachers were improvements to student-teachers' knowledge and practice; and the value of and enjoyment in working at a higher academic level. Teacher-educators also 
perceived that the M level PGCE had brought about improvements to the ITE programme overall, including support for student-teachers and improvements to student-teachers' articulation of knowledge and practice. Student-teachers perceived that the M level PGCE had brought about enhanced opportunities for employability, career advancement and gaining a masters degree. Each theme is discussed below.

\section{Improvements to student-teachers' knowledge and practice}

Both teacher-educators and student-teachers perceived that the M level PGCE had brought about improvements to student-teachers' knowledge and practice.

Teacher-educators reported improvements in student-teachers' knowledge and practice as:

Trainees became more analytical and critical.

A level of thoughtfulness and analysis I'd rarely seen in trainees' work before.

External Examiners said that trainees were more thoughtful and reflective than previously.

It is especially pertinent that these improvements are reported by External Examiners from other ITE providers, who perhaps had a more objective knowledge of student-teachers' progress and the programme before and after the move to the M level PGCE, since External Examiners undertake a quality assurance role and need to confirm that standards are at least in line with other comparable programmes in the country.

Student-teachers reported improvements in their knowledge and practice as:

Level 7 made me more analytical and critical.

I was more able to reflect critically.

Criticality and critical reflection are key features of masters level work within the level 7 descriptor of the Framework for Higher Education Qualifications (QAA 2014). Furthermore, criticality and critical reflection inform student-teachers' knowledge and practice, which will also inform their future teaching and enhance teachers' professional confidence. These findings that $\mathrm{M}$ level study in education improves student-teachers' knowledge and practice are reinforced by Revell (2005), who concluded that masters study would create a more knowledgeable teaching workforce and eradicate the current feelings of insecurity and 
inferiority that are unfortunately prevalent in the teaching profession in England. These findings also align with other literature that $\mathrm{M}$ level study has a positive impact on learning and teaching in classrooms (McAteer et al 2010; Thomas 2017). Wiliam (2010) also argues that $\mathrm{M}$ level programmes will enhance practice, if they are designed with that purpose. Clearly, regularly reflecting on and linking the teaching experience to the intended objectives in a structured way informs and improves practice (Bringle and Hatcher 1999), which is important for improving learning and teaching.

The perceptions from teacher-educators and student-teachers align with the BERA-RSA inquiry (2014) that the best ITE programmes internationally offer academic awards that are practice-focused and Jackson's (2008) findings that the M level PGCE had led to improvements in student-teachers' skills. Nevertheless, in further research, Jackson (2009) and Graham-Matheson (2010) found that the M level PGCE was not appropriate for everyone. Sewell (2008) concludes, however, that the M level PGCE is now most appropriate for the changing demands on teachers and student-teachers should be able to work at level 7 with support from university tutors. People have different levels of academic preparedness and different priorities, however, and so some student-teachers may not be ready or may not want to study at level 7 (Thomas 2013), reinforcing Graham-Matheson's (2010) research that student-teachers prioritise the professional standards above the PGCE.

The findings from this research highlight best practice in ITE, which is underpinned by principles of reflective practice (Schön 1983) and constructivist learning approaches (Dewey 1904; Piaget 1972; Bruner 1996; Perkins 1999). Teaching, it can be argued, is highly complex (TDA 2008a; The Teacher 2009), although there are some neo-conservatives who consider teaching to be merely a practical skill (DfE 2010; Carter 2015; DfE 2016), which they believe is 'best learned by the emulation of experienced practitioners' (Furlong et al 2000, 11). In effect, neo-conservatives reduce teaching to an apprenticeship model, considering that effective teachers can be borne from merely observing experienced teachers and copying them. Yet, it is crucial to note that student-teachers also perceived that the additional reading and theory had provided greater understanding:

I think the benefits are that you spend more time reading literature surrounding pedagogy and practice that you might not read otherwise. It opens your mind to different viewpoints. It allows you to do research on your own classes. 
The reading ... helped me to have more professional discussions with people in school and that way to develop my teaching.

Keeping up-to-date with current teaching theories.

These comments align with Jackson's findings (2009) that student-teachers in England considered reading to be an important aspect of working at $\mathrm{M}$ level. In addition, these comments concur with findings regarding Finnish student-teachers' appreciation of the research-based approach as the main organising theme of teacher education (Jyrhämä et al 2008). UCET (2016) also found that teachers need to be able to use research, as teachers with research skills are capable of bringing about change to enhance pupils' learning and contribute to overall school improvement. Furthermore, BERA-RSA (2014) concluded that research-informed practice is the hallmark of the very best teacher education programmes internationally and that the best ITE programmes offer academic awards that are built on relevant educational research and develop strong links between theory and practice. Such ITE helps student-teachers to understand and explore the interconnectedness of educational theories and classroom practices. In addition, Sewell and Lakin (2008) consider that studentteachers undertaking the M level PGCE develop the knowledge and understanding of educational theory and the skills and attributes necessary to enable them to apply theory to professional practice. They also stress that $\mathrm{M}$ level work requires student-teachers to link theory, research and practice, in order to undertake more sophisticated work, and to reflect more significantly on pupils' learning and their teaching skills, which should lead to improvements in pupils' attainment and classroom practice. This is an important area, as the links between theory and practice are often difficult to make (Rivero García and Porlán Ariza 2004), but pupils' learning can be greatly advanced if this issue is addressed effectively (Korthagen and Kessels 1996). The synthesis of theory with practice is an important aspect of masters level work (QAA 2014), but many student-teachers question the benefit of theory (Grove-White 2004). Jackson (2009) also found that although student-teachers at the start of the M level PGCE consider the linking of theory and practice to be beneficial in principle, in practice they thought the reality had not lived up to their expectations by the end of the course. This may mean a failing in ITE which need to be addressed or maybe identity transformation inevitably depends on socialisation with the work culture and professional integration (Thomas 2013). Also, there are many teachers who do not have masters level qualifications, but are excellent practitioners (Hoyle and Wallace 2005), so M level study is not the only pathway to becoming a 'good' teacher. Nevertheless, it is also acknowledged 
that good teachers are good learners (Loewenberg Ball and Cohen 1996). Overall, these findings also echo research claiming the benefits of $\mathrm{M}$ level study in raising standards of education and improvements in teachers' knowledge and understanding, when designed with that purpose (TDA 2008c; UCET 2008; Seabourne 2009; Wiliam 2010; Thomas 2016). Furthermore, student-teachers' greater professional confidence gained via the M level PGCE may well support professional integration and retention. In addition, these students' greater professional confidence aligns with Norwegian student-teachers' perceptions that the PGCE is necessary to be confident in the teaching role (Roness and Smith 2009).

In summary, these findings align with much seminal work and clearly demonstrate that both teacher-educators and student-teachers perceived that the M level PGCE had brought improvements to student-teachers' knowledge and practice. Furthermore, interaction with and support from university tutors and peers is very important to student-teachers' knowledge and practice. This interaction and support can be facilitated very well within university-led ITE, rather than on school-based placement, in which student-teachers can often be isolated in small primary schools or in subject departments in secondary schools.

\section{The value of and enjoyment in working at a higher academic level}

Another common theme identified from interviews with both teacher-educators and studentteachers was the value of and enjoyment in working at a higher academic level. One ITE leader responsible for overseeing and managing the work of teacher-educators reported that 'Colleagues really enjoy working at masters level.' Rhodes, Hollinshead and Nevill (2007) also found 'intellectual challenge' to be a significant facet in HE lecturers' job satisfaction, so these findings may well be positive for teacher-educators' job satisfaction and also connected issues, such as staff morale, motivation, retention and career progression. Adults also respond better to internal motivations, such as enjoyment in working at a higher level, which aligns well with an andragogical approach (Knowles 1990). Senior leaders in HE could, therefore, consider these benefits and other benefits to their institutions of academics working at higher levels, in order to enhance the professional environment, flexibility and capacity of university departments.

Student-teachers also commented:

Level 7 added a new level of challenge and enjoyment for me.

University sessions were interesting and useful. 
These findings also highlight the value of intellectual challenge and enjoyment to studentteachers, which may also be important for their future motivation, job satisfaction, retention and career progression. It appears, therefore, that working at a higher academic level is important to some student-teachers in meeting their higher needs relating to esteem and selfactualization (Maslow 1943), which in turn should benefit pupils' learning. These findings are also consistent with literature that the M level PGCE has proved to be enjoyable and valuable for student-teachers (Jackson 2009), in addition to the professional aspects of an ITE course. Student-teachers also appeared to recognise the efficacy of learning linked to the school context (Walker and Dimmock 2006) and the need to integrate the role of the school in their learning to improve links between theory and practice (Simkins 2009).

Overall, these findings highlight the value of and enjoyment in working at a higher academic level for both teacher-educators and student-teachers, aligning with much seminal work in education and psychology. It also appears that working at a higher academic level is important to both teacher-educators and student-teachers, which could in turn benefit universities and their students and schools and their pupils in a range of ways. These benefits may also be especially important and worthy of further consideration by policymakers at a time of a serious teacher supply crisis in England.

Improvements to the ITE programme overall, including support for student-teachers and improvements to student-teachers' articulation of knowledge and practice

Teacher-educators also perceived that the M level PGCE had brought about improvements to the ITE programme overall, including support for student-teachers and improvements to student-teachers' articulation of knowledge and practice. Improvements were reported as:

M level has improved lots of aspects of the course.

We have a better and more reflective programme, as a result of integrating $\mathrm{M}$ level.

The M level PGCE actually helped to support trainees better.

Trainees are also able to articulate better what they're doing in the classroom.

These teacher-educator perceptions align with Jackson's $(2008,2009)$ findings that the M level PGCE had led to improved programmes and been a success overall, with good pass rates despite the increased academic demands. These findings are consistent with literature that the M level PGCE is the most appropriate route for the current demands on teachers 
(Sewell, 2008) and aligns with Graham-Matheson's (2010) findings that the M level PGCE had been a positive change.

Teacher-educators also perceived that the M level PGCE had improved student-teachers' articulation of their practice, which is important as some experienced teachers are often unaware of their own skills and have difficulty in articulating their practice to others (Smith 2004). McAteer et al (2010) also argue that masters level study supports teachers to become more critical, analytical and reflective. Certainly, masters level study and the reading required at this level appears to give student-teachers access to a more professional type of language in which to articulate their knowledge and share practice with colleagues (Thomas 2017), which may help student-teachers in becoming accepted as colleagues by teachers and facilitate student-teachers' integration into the teaching profession. In addition, this may foster greater professional confidence and empower teachers in a turbulent climate of change in education (Thomas 2016), which may also be helpful for retention at a time of a serious teacher supply crisis in England (NAO 2016).

Clearly, these findings show the teacher-educators' perceptions that the M level PGCE has brought about improvements to the ITE programme overall, including support for studentteachers and improvements to student-teachers' articulation of knowledge and practice. This research also concurs with much literature discussed above regarding the improvements brought about by the M level PGCE and M level study, which should support studentteachers' future teaching and could also be used by policymakers to consider teacher recruitment and retention.

\section{Enhanced opportunities for employability, career advancement and gaining a masters degree}

Student-teachers perceived that the M level PGCE had brought about enhanced opportunities for employability, career advancement and gaining a masters degree. Opportunities were reported as:

My head teacher was really impressed I'd done level 7 and chosen to do more work. I think it gives you an edge at interviews.

Possible help if looking for senior management roles.

I wanted a postgraduate qualification. 
This course has given me the possibility of continuing with a masters course with already obtaining some credits.

Regarding enhanced opportunities for employability, Sewell (2008) also considers that those who undertake the M level PGCE are well-placed at interviews to articulate their knowledge of the theory and research which underpin practice. Caution may be needed, however, as Jackson's findings (2009) show that only 30\% of student-teachers at the end of their M level PGCE thought that masters level study was beneficial for employability and employability is currently not a key issue at a time of a serious teacher supply crisis in England.

Student-teacher perceptions regarding career advancement are also reinforced by Sewell (2008), who suggested that M level study would probably support teachers' career aspirations, since highly reflective teachers who can articulate their knowledge and practice well are in much demand. The enhanced professional confidence and improvements discussed above may also be beneficial in securing career advancement.

Finally, most student-teachers felt it was important to have a postgraduate qualification in education, which concurs with Jackson's research (2009). The findings appear to demonstrate student-teachers' recognition of the value of studying the discipline of education and the value of the academic award in ITE, in order to support children's learning and to support themselves to thrive in the profession. They were also aware that the M level PGCE supports later on the road to completing a full masters degree, since most HEIs accept M level PGCE credits towards a full masters degree in education via the recognition of prior certificated learning (RPCL). The vast majority of universities now offer sixty level 7 credits within the M level PGCE, meaning that those who achieve this award will gain enough credits for onethird of a masters degree in education. Some teachers have taken advantage of this opportunity, therefore, which is beneficial to their continuing professional learning (CPL) and may provide teachers with the ongoing support and inspiration necessary within a challenging profession. It has also been acknowledged above that some of the highest performing school systems across the world have a masters qualified teaching profession (McKinsey 2007; Tryggvason 2009).

In summary, these findings demonstrate student-teachers' perceptions that the M level PGCE has brought about enhanced opportunities for employability, career advancement and gaining a masters degree. Clearly student-teachers were aware that their sixty masters level credits 
from the M level PGCE would be accepted towards a full masters degree and were motivated to continue with their academic and professional learning.

\section{Conclusion}

Despite the UK government's school-led ITT agenda, this article draws upon other research from the UK and other countries (which have very high performing school systems), outlining the importance of university study for student-teachers and makes a further distinctive contribution to this key debate regarding teacher education in England. In particular, this qualitative research moves the debate forward by offering rich accounts of key stakeholder perspectives, which contribute new knowledge to the debate. The findings also move the debate forward by demonstrating the value for student-teachers in studying the discipline of education and gaining a good understanding of education, in order to inform their future teaching. The value of the academic award in ITE via the masters level PGCE is discussed in particular, although the findings are also highly relevant to undergraduate ITE programmes and also to $\mathrm{M}$ level study for in-service teachers. The findings reveal two common themes from teacher-educators and student-teachers: improvements to studentteachers' knowledge and practice; and the value of and enjoyment for both teacher-educators and student-teachers in working at a higher academic level. Teacher-educators also perceived that the M level PGCE had brought about improvements to the ITE programme overall, including student-teacher support and student-teachers' articulation of knowledge and practice. Finally, student-teachers perceived that the M level PGCE had brought about enhanced opportunities for employability, career advancement and gaining a masters degree.

Clearly, the study of education and the academic award in ITE have real strengths which are important to the work of teachers. The accounts from key stakeholders reveal important insights, which could be used in turn by policymakers to inform school improvement and raise the status of the teaching profession to ultimately benefit children, teachers, the teaching profession and education overall. Furthermore, findings could be used by policymakers to reconsider in-service professional learning and education for teachers, since there is currently no coherent strategy in England and also to reconsider recruitment and retention strategies during a teacher supply crisis.

It is acknowledged that good teachers are good learners (Loewenberg Ball and Cohen 1996) and that ITE should prepare teachers who are continuous learners themselves (Livingston and Shiach 2010). Furthermore, this research could be used by university education departments 
to better articulate the value of the academic award in education - both in ITE and in CPL. Successive governments and reviews (see Carter 2015) have advocated the minimum, essential professional award of QTS, in order to satisfy their own ideological stance and in an attempt to address a teacher supply crisis as a 'quick fix', rather than in a strategic manner. There is a real need, however, for a strategic review of key matters, such as ways to improve the status of teachers, teachers' workload and succession planning, in addition to raising standards in learning and teaching, with the ultimate aim of improving children's life chances.

Trade unions, professional associations and progressive alliances with a membership which includes student-teachers, teachers and university teacher-educators could also work more collaboratively together to engage policymakers in discussions with the aim of reducing the workload of teachers, which is known to be problematic (Rhodes, Nevill and Allan 2004; DfE 2015; Thomas 2017) and also securing university teacher-educators' jobs, by highlighting the value of academic studies in education and university-led ITE for teachers. Many teachers and school leaders are now spending much less time on their core purpose of pupils' learning and much time out of the classroom to train the next generation of teachers due to the advance of school-led ITT, whilst university teacher-educators are being pushed out of a core role they have successfully undertaken for many years and despite the UK having one of the best HE systems in the world (Quacquarelli Symonds 2016). Since the move to student-teachers spending half of ITE programmes on placement, there has been much greater and meaningful university-school partnerships, which was working well as student-teachers do need to gain significant classroom experience in schools working alongside experienced teachers as their mentors. In the last two decades, teachers have been put under significant pressure, due to the whirlwind of interventions, strategies, ideological shifts and policies launched within education (Chapman and Gunter 2009) and more and more is expected of teachers within a regime dominated by the need for performativity (Ball 2003). In fact, it is only university education departments which have the capacity and expertise to successfully recruit, educate and train large numbers of student-teachers to effectively address the recruitment crisis, yet political ideology for school-led ITT is still taking priority.

The findings regarding the M level PGCE highlight the value of the academic award in ITE and challenge the technicist view of teaching as a 'craft', since the foundations provided by theory within the M level PGCE/ academic award in ITE enable student-teachers to thrive, 
rather than survive, within the complexities and challenges of the teaching profession in England. As the UK is now the sixth most unequal developed country in the world and this inequality is increasing (OECD 2015), it is essential that policymakers review school improvement and teacher education strategies in partnership with experts in university education departments, rather than ignoring, marginalising and dismissing the views of higher education within a new anti-academic culture which seems determined to see the demise of the expert view and knowledge (Gibb 2014; Brundrett 2015; Nichols 2017).

A future generation of teachers without an underpinning knowledge of education and pedagogy is a worrying prospect for children's life chances. Accounts from these key stakeholders reveal important insights and new knowledge regarding the value of academic studies in education and the value of the academic award in ITE as a positive way forward for school improvement and teacher education. These findings could be used by policymakers to address crucial matters in supporting pupils' learning; improve the professional confidence and status of the teaching profession; address aspects of recruitment, professional integration and retention to alleviate the teacher supply crisis; and enhance teachers' job satisfaction, motivation and career progression, ultimately benefitting children, young people, the teaching profession and education in schools overall. Recently, there was some reason for optimism, however, as the former Secretary of State for Education seemed to be adopting a more pragmatic approach that embraced university-led ITE, rather than pursuing the ideological advance towards school-led ITT (Hazell and Ward 2017). This approach aligned with the DfE's renewed remit for universities, since the eminently sensible decision to move universities from the Department for Business, Innovation and Skills (BIS) and back into the Department for Education. Following the recent government Cabinet reshuffle, however, which removed the former Secretary of State for Education from her post after only eighteen months, we now have to wait to see the approach to be taken by yet another new Secretary of State for Education. Finally, if education strategy is to engage effectively with the complexities of learning and teaching and address school improvement and the teacher supply crisis in a more meaningful and strategic way, however, the commitment by policymakers to invest in partnership with universities for ITE and CPL would appear to be an essential prerequisite and an effective alternative to the current technicist model of schoolled ITT and the current fragmented system in England. 


\section{References}

Ball, S. J. 2003 "The teacher's soul and the terrors of performativity." Journal of Education Policy 18 (2): 215-228.

BERA (British Educational Research Association) and RSA (Royal Society for the encouragement of Arts, Manufactures and Commerce) 2014 Research and the Teaching Profession; building the capacity for a self-improving education system. Final report of the BERA-RSA Inquiry into the role of research in teacher education. London: BERA

Bringle, R. and Hatcher, J. 1999 "Reflection in service-learning: Making meaning of experience." Educational Horizons: 179-185.

Brown, D. and Evans, J. 2004 "Reproducing Gender? Intergenerational Links and the Male PE Teacher as a Cultural Conduit in Teaching Physical Education." Journal of Teaching in Physical Education 23: 48-70

Brundrett, M. 2015 "Policy on the primary curriculum since 2010: The demise of the expert view" London Review of Education 13 (2): 49-59

Bruner, J. 1996 The Culture of Education. Cambridge, MA: Harvard University Press

Carter, A. 2015 Carter review of initial teacher training. London: Department for Education

Chapman, C. and Gunter, H. 2009 Radical Reforms: Perspectives on an era of educational change. Abingdon: Routledge

Denscombe, M. 2003 The Good Research Guide for small scale research projects. ( $2^{\text {nd }}$ ed) Maidenhead: OUP.

DCSF (Department for Children, Schools and Families) 2007 The Children's Plan Nottingham: DCSF

DfE (Department for Education) 2010 The Importance of Teaching: The Schools White Paper London: Her Majesty's Stationery Office

DfE (Department for Education) 2012 Teachers' Standards London: Her Majesty's Stationery Office

DfE (Department for Education) 2015 Government response to the Workload Challenge London: DfE

DfE (Department for Education) 2016 Educational Excellence Everywhere London: DfE

Dewey, J. 1904 The Relation of Theory to Practice in Education. Chicago: The University of Chicago Press

Donaldson, G. 2011 Teaching Scotland's Future: Report of a review of teacher education in Scotland Edinburgh: The Scottish Government 
Furlong, J., Barton, L., Miles, S., Whiting, C. and Whitty, G. 2000 Teacher Education in Transition: re-forming professionalism? Buckingham: Open University Press

Furlong, J. 2015 Teaching tomorrow's teachers: Options for the future of initial teacher education in Wales Oxford: University of Oxford

Gibb, N. 2014 "Teaching unions aren't the problem - universities are.” The Guardian, April 24. http://www.theguardian.com/commentisfree/2014/apr/23/teaching-unions-arent-problemuniversities-schools-minister

Given, L.M. ed. 2008 The Sage Encyclopaedia of Qualitative Research Methods Vol. 2, Thousand Oaks, CA: Sage

Gomm, R., Hammersley, M. and Foster, P. eds. 2000 Case study method: Key issues, key texts. London: Sage

Graham-Matheson, L, 2010 "Masters of the game: teacher educators and the M level PGCE." Teacher Education Advancement Network Journal 1 (1): May

Grove-White, A. 2004 Students' understanding of the relationship between theory and practice in A. Davies ed 2004 Enhancing curricula: Exploring Effective Practices in Art and Design and Communication London: Centre for Learning and Teaching in Art and Design

Hazell, W. and Ward, H. 2017 "Exclusive: DfE declares ceasefire in war on university teacher-training departments" Times Educational Supplement, March 10

https://www.tes.com/news/school-news/breaking-news/exclusive-dfe-declares-ceasefire-waruniversity-teacher-training

Hoyle, E. and Wallace, M. 2005 Educational Leadership: Ambiguity, Professionals and Managerialism London: Sage

Jackson, A. 2008 “How could Master's-level PGCEs affect CPD?” CPD Update e-bulletin http://www.teachingexpertise.com/articles/how-could-masters-level-pgces-affect-cpd-3171

Jackson, A. 2009 "Perceptions of Masters level PGCE: A pilot investigation." The University of Cumbria and the ESCalate Initial Teacher Education Subject Centre of the Higher Education Academy http://escalate.ac.uk/downloads/6461.pdf

Jyrhämä, R., Kynäslahti, H., Krokfors, L., Byman, R., Maaranen, K., Toom, A. and Kansanen, P. 2008 "The appreciation and realisation of research- based teacher education: Finnish students' experiences of teacher education." European Journal of Teacher Education 31 (1): $1-16$

Knowles, M. 1999 The Adult Learner: A Neglected Species ( $4^{\text {th }}$ ed) Houston: Gulf Publishing Company

Korthagen, F. A. J. and Kessels, J. P. A. 1999 "Linking Theory and Practice: Changing the Pedagogy of Teacher Education.” American Educational Research Association 28 (4): 4-17

Livingston, K. and Shiach, L. eds. 2010 "Co-constructing a new model of teacher education." 
In Campbell, A. and Groundwater-Smith, S. Connecting Inquiry and Professional Learning in Education: International perspectives and practical solutions London: Routledge, 83-95

Loewenberg Ball, D. and Cohen, D. K. 1996 "What Is: Or Might Be: The Role of Curriculum Materials in Teacher Learning and Instructional Reform?" Educational Researcher 25 (9): 614.

Maslow, A. 1943 “A theory of human motivation.” Psychological Review 50: 370-96

McAteer, M., Murtagh, L., Hallett, F. and Turnbull, G. 2010 Achieving your Masters in Teaching and Learning Exeter: Learning Matters Ltd

McKinsey \& Company 2007 How the world's best-performing schools come out on top http://www.mckinsey.com/locations/ukireland/publications/pdf/Education_report.pdf

Merriam, S. 2009 Qualitative Research: A guide to design and implementation. San Francisco CA: Jossey Bass.

Miles, M. B. and Huberman, A. M. 1994 Qualitative Data Analysis ( $2^{\text {nd }}$ ed). London: Sage.

NAO (National Audit Office) 2016 Training new teachers https://www.nao.org.uk/wpcontent/uploads/2016/02/Training-new-teachers.pdf

Nichols, T. 2017 The Death of Expertise: The Campaign against Established Knowledge and Why it Matters USA: OUP

Ofsted (Office for Standards in Education, Children's Services and Skills) 2010a The Annual Report of Her Majesty's Chief Inspector of Education, Children's Services and Skills 2009/ 10 London: The Stationery Office

Ofsted (Office for Standards in Education, Children's Services and Skills) 2010b Initial teacher education inspection handbook Manchester: Ofsted

OECD (Organisation for Economic Co-operation and Development) 2015 In It Together: Why Less Inequality Benefits All Paris: OECD Publishing

Palinkas, L.A., Horowitz, S.M. and Hoagwood, K. 2015 "Purposeful sampling for qualitative data collection and analysis in mixed methods implementation research" Administration and policy in mental health 42 (5): 533-544

Patton, M.Q. 2002 Qualitative Research and Evaluation Methods $\left(3^{\text {rd }}\right.$ ed). Thousand Oaks CA: Sage.

Perkins, D. 1999 “The Many Faces of Constructivism.” Educational Leadership 57 (3): 6-11

Piaget, J. 1972 The principles of genetic epistemology. New York: Viking

QAA (Quality Assurance Agency for Higher Education) 2014 UK Quality Code for Higher Education Part A: Setting and Maintaining Academic Standards The Frameworks for Higher Education Qualifications of UK Degree-Awarding Bodies Gloucester: QAA 
QS (Quacquarelli Symonds) 2016 Higher Education System Strength Rankings http://www.topuniversities.com/system-strength-rankings/2016

Revell, P. 2005 The Professionals: Better teachers, better schools Stoke-on-Trent: Trentham Books

Rhodes, C. P., Hollinshead, A. and Nevill, A. 2007 "Changing times, changing lives: a new look at job satisfaction in two university Schools of Education located in the English West Midlands." Research in Post-Compulsory Education 12 (1): 71-89

Rhodes, C. P, Nevill, A. and Allan, J. 2004 "Valuing and Supporting Teachers: A Survey of Teacher Satisfaction, Dissatisfaction, Morale and Retention within an English Local Education Authority." Research in Education 71: 67-80

Rivero García, A. and Porlán Ariza, R. 2004 "The difficult relationship between theory and practice in an in-service course for science teachers" International Journal of Science Education 26 (10): 1223 - 1245

Roness, D. and Smith, K. 2009 "Postgraduate Certificate in Education (PGCE) and student motivation." European Journal of Teacher Education 32 (2) May 2009: 111-134

Schön, D. A. 1983 The Reflective Practitioner: How professionals think in action. New York: Basic Books

Seabourne, P. 2009 A longitudinal review of the postgraduate professional development of teachers London: TDA

Sewell, K. 2008 ed. Doing your PGCE at M-level London: Sage

Sewell, K. and Lakin, L. 2008 What will the PGCE at M-level do for me? in K. Sewell ed. 2008 Doing your PGCE at M-level London: Sage

Simkins, T, 2009 "Integrating work-based learning into large-scale national leadership development programmes in the UK" Educational Review 61(4): 391-405.

Simon, B. 1981 Why no pedagogy in England? in B. Simon and W. Taylor eds. Education in the Eighties: the central issues London: Batsford

Smith, J. 2004 “Developing Paired teaching Placements" Educational Action Research 12 (1): 99-126

The Teacher 2009 April edition London: NUT

Thomas, L. 2013 "An analysis of PGCE models: Key stakeholder perceptions from the secondary phase. Teacher Education Advancement Network 5 (3): 4-16

Thomas, L. 2016 "Aspirations for a master's-level teaching profession in England." Professional Development in Education 42 (2): 218-234 
Thomas, L. 2017 "The Masters in Teaching and Learning: Lessons to be learnt and key stakeholder perceptions" Teacher Education Advancement Network 9(1): 45-55

TDA (Training and Development Agency for Schools) 2008a National MTL consultation events

TDA (Training and Development Agency for Schools) 2008b Regional MTL consultation events

TDA (Training and Development Agency for Schools) 2008c PPD Impact Evaluation Report London: TDA

Tryggvason, M-T. 2009 "Why is Finnish teacher education successful? Some goals Finnish teacher educators have for their teaching." European Journal of Teacher Education 32 (4): 369-382

Tucker, S.A. 1999 “Making the Link: Dual 'Problematization', Discourse and Work with Young People" Journal of Youth Studies 2 (3): 283-295

UCET (Universities' Council for the Education of Teachers) 2008 Report of the UCET Annual Conference 2008: Changing policy, changing practice in teacher education UCET: London

UCET (Universities' Council for the Education of Teachers) 2016 The benefits to individual teachers, to schools and to the teaching profession of Masters level Initial Teacher Education London: UCET

UUK (Universities UK) 2014 The Impact of Initial Teacher Training Reforms on English Higher Education Institutions London: UUK

Walker, A. and Dimmock, C. 2006 "Preparing leaders, preparing learners: The Hong Kong experience" School Leadership and Management 26 (2): 125-147

Wiliam, D. 2010 Teachers TV: Masters in Teaching and Learning. https://www.tes.com/teaching-resource/teachers-tv-masters-in-teaching-and-learning6044514 